\title{
Pemberdayaan Keluarga dan Kader Kesehatan dalam Pemanfaatan ASI Eksklusif
}

\author{
Sukmawati, Lilis Mamuroh, Furkon Nurhakim \\ Fakultas Keperawatan, Universitas Padjadjaran \\ Email: sukmawati@unpad.ac.id
}

\begin{abstract}
Abstrak
Di Indonesia saat ini $40 \%$ kematian balita terjadi pada 1 bulan pertama kehidupan bayi, dengan pemberian ASI akan mengurangi 22\% kematian bayi dibawah umur 28 hari. Sedangkan persentase bayi yang menyusu eksklusif baru mencapai 15,3\%, Puskesmas Gadog memiliki cakupan ASI Esklusif 62,6\% sedangkan target Dinas Kesehatan Kabupaten Garut 64\%. Perilaku menyusui berkaitan dengan pengetahuan yang kurang, kepercayaan atau persepsi dan sikap yang salah dari ibu mengenai ASI, sehingga dukungan keluarga, tenaga kesehatan dan masyarakat sangat diperlukan agar ibu dapat menyusui secara eksklusif. Tujuan dari kegiatan ini terlaksananya upaya pemanfaatan ASI eksklusif oleh ibu melalui peningkatan pengetahuan dan peran aktif keluarga dan kader kesehatan dalam memberikan motivasi pada ibu hamil. Metode pelaksanaan Program Pengabdian Masyarakat ini adalah ceramah, diskusi dan demonstrasi. Jumlah peserta yang hadir dalam pelatihan ini berjumlah 31 orang yang terdiri dari keluarga ibu hamil 19 orang serta kader kesehatan 12 orang. Uji analisis yang digunakan adalah Wilcoxon. Hasil penelitian didapatkan rata-rata pengetahuan sebelum pelatihan 61,54 dan setelah pelatihan 76,05 , rata-rata skill sebelum pelatihan 60,15 dan setelah pelatihan 73,89 . Berdasarkan uji analisis wilcoxon ada perubahan signifikan dalam pengetahuan dan skill dengan masing-masing $p$ value 0,000. Kesimpulan terdapat perubahan yang signifikan dari pengetahuan dan skill keluarga dan kader kesehatan sebelum dan sesudah pelatihan. Setelah kegiatan pelatihan ini diharapkan keluarga dan kader kesehatan dapat berperan aktif untuk menyampaikan informasi kepada ibu hamil tentang manfaat ASI Aksklusif.
\end{abstract}

Kata kunci : Pemberdayaan, keluarga, kader kesehatan, ASI Eksklusif.

\begin{abstract}
Currently in Indonesia, 40\% of baby mortality occur in the first month of a baby's life. Breastfeeding is claimed to be able to reduce $22 \%$ the death of infants under the age of 28 days. While the percentage of exclusively breastfed infants just reaches $15.3 \%$, Gadog Health Center has $62.6 \%$ of Exclusive Breastfeeding coverage which is still under the target of Garut District Health Service that is 64\%. The decrease of breastfeeding activity is usually caused by the lack of knowledge, beliefs, or perceptions, and wrong attitudes of mothers regarding breastfeeding. Therefore, family support, health workers and the community are highly needed so that mothers can breastfeed exclusively. The purpose of this program is to improve mother's exclusive breastfeeding by increasing the knowledge and active role of families and health cadres in providing motivation to pregnant women. The implementation of this Community Service Program was done through lectures, discussions and demonstrations. The number of participants who attended the training was 31 people consisting of pregnant woman families, 19 people and 12 health cadres. The test analysis used was Wilcoxon. The results show that the average knowledge of the family and cadres before training is 61.54 and that of after training is 76.05. Moreover, their average skill before training is 60.15 and that of after training is 73.89. Based on the result of Wilcoxon analysis, there are significant changes in knowledge and skills with p-value 0,000 respectively. In conclusion, there are significant changes in family and health cadres knowledge and skills before and after training. After this training, it is expected that the family and health cadres can play an active role in providing information to pregnant women about the benefits of exclusive breastfeeding.
\end{abstract}

Keywords: Exclusive breastfeeding, empowerment, family, health cadres. 


\section{Pendahuluan}

Makanan pertama dan utama bayi adalah Air Susu Ibu (ASI) . ASI cocok sekali untuk memenuhi kebutuhan bayi dalam segala hal, karbohidrat dalam ASI berupa laktosa, lemaknya banyak mengandung polyunsaturated fatty acid (asam lemak tak jenuh ganda), protein utamanya lactalbumin yang mudah dicerna, kandungan vitamin dan mineralnya banyak rasiokalsium-fosfat sebesar $2: 1$ yang merupakan kondisi ideal bagi penyerapan kalsium. Selain itu, ASI juga mengandung zat anti infeksi (Arisman, 2010)

ASI adalah makanan bayi yang paling penting terutama pada bulan bulan pertama kehidupan. Asi eksklusif atau lebih tepat pemberian Asi secara Eksklusif adalah bayi hanya diberi ASI saja tanpa tambahan cairan lain seperti susu formula, jeruk, madu, air, teh, air putih tanpa tambahan makanan padat seperti pisang, pepaya, bubuk susu, biskuit, bubur nasi, dan tim (Roesali, 2008).

ASI tak ternilai harganya, selain meningkatkan kesehatan dan kepandaian secara optimal, ASI juga membuat anak potensial, memiliki emosi yang stabil, spiritual yang matang, serta memiliki perkembangan sosial yang baik (Roesali, 2008) Delapan puluh persen perkembangan otak anak dimulai sejak dalam kandungan sampai usia 3 tahun yang dikenal dengan periode emas, oleh karena itu diperlukan pemberian ASI eksklusif selama 6 bulan dan dapat diteruskan sampai anak berusia 2 tahun. Hal tersebut dikarenakan ASI mengandung protein, karbohidrat, lemak dan mineral yang dibutuhkan bayi dalam jumlah yang seimbang (Depkes, 2011).

Memberi ASI pada bayi merupakan proses alami sebagai kewajiban seorang ibu yang mengasuh anaknya. Proses alami pembentukan ASI sudah dimulai saat terjadi kehamilan, karena bersama dengan hamil payudara telah disiapkan sehingga setelah bayi lahir ibu bisa segera memberikan ASI pada bayinya (Manuaba, 2009) Banyak manfaat yang diperoleh dari ASI dibanding dengan susu formula karena ASI merupakan makanan yang paling cocok untuk bayi selain kandungan gizinya sesuai dengan kebutuhan bayi, mudah didapat, praktis penggunaannya, murah, dapat menjalin hubungan kasih sayang antara ibu dan bayi serta mengandung anti bodi yang dapat meningkatkan kekebalan tubuh pada bayi.

Air susu ibu bisa mencerdaskan dan meningkatkan kualitas generasi bangsa, setiap bayi yang diberi ASI akan mempunyai kekebalan alami terhadap penyakit karena ASI banyak mengandung antibody, zat kekebalan aktif yang akan melawan masuknya 
infeksi kedalam tubuh bayi. Saat ini $40 \%$ kematian balita terjadi pada 1 bulan pertama kehidupan bayi, dengan pemberian ASI akan mengurangi 22\% kematian bayi dibawah umur 28 hari, dengan demikian kematian bayi dan balita dapat dicegah melalui pemberian ASI ekslusif secara dini sejak bayi dilahirkan diawal kehidupannya (Roesali, 2008).

Persiapan menyusui pada masa kehamilan merupakan hal yang penting sebab dengan persiapan yang lebih baik maka ibu lebih siap untuk menyusui bayinya baik persiapan psikologi ibu untuk menyusui pada saat kehamilan sangat berarti, karena keputusan atau sikap ibu yang positif harus terjadi pada saat kehamilan atau bahkan jauh sebelumnya maupun persiapan fisik berupa pemeriksaan payudara (Soetiningsih, 2012).

Pemberian ASI di Indonesia hingga saat ini masih banyak menemui kendala dan upaya meningkatkan perilaku menyusui pada ibu yang memiliki bayi khususnya ASI ekslusif masih dirasa kurang. Data Riset Kesehatan Dasar (Riskesda) tahun 2010 menunjukkan pemberian ASI di Indonesia masih memprihatinkan, persentase bayi yang menyusui eksklusif sampai dengan 6 bulan hanya 15,3\%. Hal ini disebabkan kesadaran masyarakat dalam mendorong peningkatan pemberian ASI masih relatif rendah (Depkes, 2011). Menurut Dinas Kesehatan Kabupaten Garut tahun 2016 Puskesmas Gadog memiliki cakupan ASI Esklusif yang belum mencapai target yaitu hanya $62,6 \%$ sedangkan target Dinas Kesehatan Kabupaten Garut 64\%.

Masih rendahnya cakupan pemberian ASI eksklusif disebabkan oleh beberapa faktor, antara lain: a). ASI yang kurang; b). Bayi yang rewel/cengeng; c). Ibu yang bekerja; d). Kepercayaan masyarakat yang tidak mendukung; e). Pengetahuan tentang ASI yang kurang; f). Ibu sakit/tidak bisa menyusui serta g). Gencarnya promosi susu formula (Depkes, 2011).

Kendala ibu dalam menyusui ada dua faktor yaitu faktor internal kurangnya pengetahuan ibu tentang manajemen laktasi dan faktor eksternal ASI belum keluar pada hari-hari pertama sehingga ibu berpikir perlu tambah susu formula, ketidak mengertian ibu tentang kolostrum dan banyak ibu yang masih beranggapan bahwa ASI ibu kurang gizi, kualitasnya tidak baik (Baskoro, 2008).

Menurut Fikawati dan Syafiq (2010), alasan yang menjadi penyebab kegagalan praktek ASI eksklusif bermacam-macam seperti misalnya budaya memberikan makanan 
pralaktal, memberikan tambahan susu formula karena ASI tidak keluar, menghentikan pemberian ASI karena bayi atau ibu sakit, ibu harus bekerja, serta ibu ingin mencoba susu formula. Kurangnya sikap, pengertian dan pengetahuan ibu tentang manfaat ASI menjadi faktor terbesar yang menyebabkan ibu-ibu muda terpengaruh dan beralih kepada susu botol atau susu formula. Selain itu, gencarnya promosi susu formula dan kebiasaan memberikan makanan/ minuman secara dini pada sebagian masyarakat, menjadi pemicu kurang berhasilnya pemberian ASI maupun ASI eksklusif.

Perilaku menyusui berkaitan dengan pengetahuan yang kurang, kepercayaan atau persepsi dan sikap yang salah dari ibu mengenai ASI. Dukungan suami, keluarga, tenaga kesehatan dan masyarakat sangat diperlukan agar ibu dapat menyusui secara eksklusif. Ibu sebagai bagian dalam keluarga memegang peranan sangat penting dalam upaya ini. Perubahan sikap akan tergantung pada sejauh mana komunikasi itu diperhatikan, dipahami dan diterima.

Sejalan dengan teori Adiningsih (2004) dalam Sartono dan Utaminingrumm (2012) bahwa dukungan keluarga terutama suami dapat menentukan keberhasilan pemberian ASI eksklusif karena dukungan suami dapat memberikan rasa nyaman pada ibu yang dapat mempengaruhi produksi ASI, meningkatkan semangat dan memberikan rasa nyaman selama menyusui. Kesuksesan pemberian ASI eksklusif juga memerlukan banyak dukungan dan partisipasi dari berbagai fihak termasuk dari kader kesehatan karena kader kesehatan orang yang sering bersosialisasi dengan masyarakat termasuk ibu hamil dan menyusui (Handayani \& Aprilina, 2017)

Tujuan dari pengabdian pada masyarakat ini adalah terlaksananya upaya pemanfaatan ASI eksklusif oleh ibu melalui peningkatan pengetahuan dan peran aktif keluarga dan kader kesehatan dalam memberikan motivasi pada ibu hamil. Berdasarkan uraian tersebut diatas salah satu upaya untuk meningkatkan cakupan tentang pemberian ASI ekslusif penulis melakukan kegiatan Pengabdian Kepada Masyarakat (PKM) dengan judul "Pemberdayaan Keluarga Dalam Pemanfatan ASI Ekslusif" kegiatan ini diharapkan dapat menjadi bagian solusi dari masalah pemanfaatan ASI eksklusif.

\section{Metode}

Metode pelaksanaan Program Pengabdian Masyarakat ini adalah ceramah, diskusi dan demonstrasi. Peserta yang hadir terdiri dari kader kesehatan yang terdaftar di Puskesmas 
Gadog dan mendapat undangan dari fihak Puskesmas untuk mengikuti pelatihan dan setiap kader dianjurkan untuk membawa keluarga ibu hamil minimal 1 kader membawa perwakilan dari keluarga 1-2 orang. Jumlah peserta yang hadir dalam pelatihan ini berjumlah 31 orang yang terdiri dari keluarga ibu hamil 19 orang serta kader kesehatan 12 orang (satu Desa diwakili oleh dua orang kader kesehatan). Sesi ke 1 kegiatan dimulai dari tahap perencanaan yang diawali dengan dengan survey tempat pelaksanaan kegiatan, menetapkan sasaran yaitu keluarga ibu hamil dan kader kesehatan, menyiapkan materi tentang ASI eksklusif, pembuatan proposal dan penyelesaian perizinan tempat/lokasi kegiatan pengabdian pada masyarakat. Sesi ke 2 pelaksanaan, pada fase ini pengusul PPM berkoordinasi dengan Bidan Koordinator dan Kepala Puskesmas untuk menyepakati kembali tujuan dari pelaksanaan kegiatan. Selanjutnya pengusul PPM mempersiapkan kegiatan penyuluhan berupa materi dan media yang digunakan (powerpoint dan leaflet) serta mengkoordinasikan rencana kegiatan dengan peserta kegiatan, fiksasi waktu dan tempat kegiatan. Waktu pelatihan dilaksanakan pada tanggal 26 Januari sampai 1 Februari 2018 dan tempat kegiatan dilaksanakan di Puskesmas Gadog Kecamatan Pasirwangi Kabupaten Garut.

Materi yang disampaikan dalam kegiatan ini menggunakan metode ceramah dan diskusi meliputi : pengertian ASI, pengertian ASI eksklusif, jenis dan komposisi ASI, manfaat ASI, Produksi ASI, langkah-langkah menyusui yang benar, tujuh keberhasilan ASI eksklusif dan ASI ekslusif untuk ibu bekerja. Untuk Skill dilakukan dengan cara melakukan demonstrasi tentang langkah-langkah menyusui yang baik dan benar. Evaluasi pelatihan pengetahuan dilakukan dengan pretest dan post test sedangkan untuk skill menggunakan lembar observasi, untuk signifikansi kegiatan pelatihan terhadap pengetahuan dan skill peserta dilakukan uji distribusi dan analisis inferensial dengan uji wilcoxon. Sedangkan untuk mengevaluasi skill peserta tentang langkah-langkah menyusui yang benar dilakukan dengan melihat kemampuan peserta dengan mempergunakan format observasi.

\section{Hasil}

Kegiatan pengabdian ini mendapat respon yang positif dari petugas puskesmas, keluarga ibu hamil dan kader kesehatan, hal ini dibuktikan dengan mereka mengiktui kegiatan pelatihan dari awal sampai akhir. Kegiatan ini dibagi menjadi 3 tahap yaitu a 
persepsi dengan brain storming, pemberian materi dan evaluasi. Tahap pertama yaitu melakukan diskusi dengan petugas Puskesmas dan Kader Kesehatan terkait dengan informasi mengenai ASI eksklusif dan fenomena tentang pemberian ASI eksklusif pada bayi di Puskesmas Gadog. Jumlah peserta yang hadir 31 orang. Materi pelatihan berupa pengenalan tentang pengertian ASI, pengertian ASI eksklusif, jenis dan komposisi ASI, manfaat ASI, Produksi ASI, langkah-langkah menyusui yang benar, tujuh keberhasilan ASI eksklusif dan ASI ekslusif untuk ibu bekerja. Adapun karakteristik peserta yang mengikuti pelatihan adalah sebagai berikut :

Tabel 1 Karakteristik peserta pelatihan pemberdayaan keluarga dalam pemanfaatan ASI Eksklusif di Puskesmas Gadog (N=31)

\begin{tabular}{llll}
\hline No & Variabel & $\mathrm{N}$ & Persentase (\%) \\
\hline 1. & Umur & & \\
& 20-35 tahun & 24 & 77,4 \\
& $>35-45$ tahun & 5 & 16,1 \\
& $>45$ tahun & 2 & 6,5 \\
\hline 2. & Pekerjaan & & \\
& Tidak Bekerja/ IRT & 24 & 77,4 \\
& Bekerja/Sawasta/PNS & 7 & 22,6 \\
\hline 3. & Pendidikan & & 19,4 \\
& SD & 6 & 38,7 \\
& SLTP & 12 & 32,3 \\
& SLTA & 10 & 9,7 \\
& PT & 3 & \\
\hline P. & Pernah mendapatkan edukasi & & 32,3 \\
& tentang manfaat ASI Eksklusif & & 67,7 \\
& Ya & 10 & \\
& Tidak & 21 & \\
\hline
\end{tabular}

Dari tabel diatas dapat dilihat bahwa usia peserta sebagian besar berusia 20-35 tahun 24 orang $(77,4 \%)$. Sebagian besar peserta yaitu 24 orang $(77,4 \%)$ status pekerjaannya adalah tidak bekerja atau ibu rumah tangga, sebagian besar peserta yaitu 12 orang $(38,7 \%)$ berpendidikan SLTP, Sebagian besar peserta yaitu 21 orang $(67,7 \%)$ belum pernah mendapat edukasi tentang manfaat ASI eksklusif.

Uji distribusi pengetahuan dan skill peserta yang dilakukan sebelum dan sesuadah pelatihan dapat dilihat pada tabel dibawah ini. 
Tabel 2 Hasil Uji Perbedaan Rata-rata Pengetahuan Peserta Sebelum Dan Sesudah Pelatihan Tentang Manfaat ASI Eksklusif (N=31)

\begin{tabular}{llll}
\hline Tingkat Pengetahuan & Mean & SD & P value \\
\cline { 1 - 3 } Sebelum edukasi & 61,54 & 20,73 & \\
\cline { 1 - 3 } Sesudah edukasi & 76,05 & 18,44 & 0,000 \\
\hline
\end{tabular}

Uji perbedaan rata-rata pengetahuan peserta yang dilakukan sebelum pelatihan tentang manfaat ASI eksklusif adalah 61,54 dan sesudah pelatihan 76,05. Terdapat pengaruh yang signifikan pengetahuan responden sebelum dan sesudah pelatihan $\mathrm{p}$ value $(0.000)$.

Tabel 3 Hasil Uji Perbedaan Rata-rata Skill Peserta Sebelum Dan Sesudah Pelatihan Tentang Manfaat ASI Eksklusif (N=31)

\begin{tabular}{llll}
\hline Tingkat Pengetahuan & Mean & SD & P value \\
\cline { 1 - 3 } Sebelum edukasi & 60,15 & 20,99 & \\
\cline { 1 - 3 } Sesudah edukasi & 73,89 & 16,93 & 0,000 \\
\hline
\end{tabular}

Uji perbedaan rata-rata skill peserta tentang langkah-langkah menyusui yang baik dan benar yang dilakukan sebelum pelatihan adalah 60,15 dan sesudah pelatihan 73,89 . Terdapat pengaruh yang signifikan skill responden sebelum dan sesudah pelatihan pvalue (0.000).

\section{Pembahasan}

Kegiatan pengabdian pada masyarakat tentang pemberdayaan keluarga dan kader kesehatan di Puskesmas Gadog memberikan dampak perubahan pengetahuan tentang manfaat ASI eksklusif dan skill tentang langkah-langkah menyusui yang baik dan benar. Pada awal kegiatan brainstorming dan hasil pre test sebagian besar belum memahami tentang ASI eksklusif termasuk cara menyusui yang benar. Para peserta yang hadir sangat antusias selama mengikuti pelatihan karena sebagian besar baru pertama kali mengikuti pelatihan tentang manfaat ASI eksklusif dan langkah-langkah menyusui dengan baik dan benar, walaupun pada awal kegiatan sesi brainstorming beberapa peserta menyampaikan pendapatnya tentang manfaat ASI eksklusif namun secara keseluruhan peserta belum memahami secara jelas tentang manfaat ASI eksklusif dan langkah-langkah menyusi yang baik dan benar. 
Adanya informasi tentang manfaat ASI eksklusif dan langkah-langkah menyusi yang baik dan benar dapat meningkatkan pengetahuan dan skill bagi peserta pelatihan. Hal ini sejalan dengan teori Notoatmodjo (2012) bahwa ada beberapa faktor yang berhubungan tingkat pengetahuan seseorang antara lain umur, pendidikan, sosiall budaya dan ekonomi, lingkungan, pengalaman dan informasi yang diterima.

Peningkatan pengetahuan dan skill peserta tentang manfaat ASI eksklusif didukung dengan hasil penelitian Hilala (2014) terdapat hubungan antara pengetahuan dengan pemberian ASI eksklusif pada masyarakat di wilayah kerja Puskesmas Tuladenggi Kecamatan Telaga Biru. Menurut Notoadmodjo (2012), informasi yang di dapat seseorang terkait pemberian ASI eksklusif dapat mempengaruhi perilaku orang tersebut dalam memberikan ASI eksklusif.

Dari hasil penelitian sebelumnya yang dilakukan Hilala (2014) menyatakan banyak ibu yang bersikap kurang mendukung pemberian ASI, hal ini salah satunya disebabkan karena pengaruh dari lingkungan sekitar. Dimana lingkungan sekitar sangat mempengaruhi seseorang untuk mengambil keputusan yang terbaik. Karena pada zaman modern sekarang ini semakin banyak promosi susu formula yang dianggap praktis oleh ibu-ibu.

.Tujuan belajar adalah menimbulkan perubahan disalah satu atau lebih ranah (bidang, domain) yaitu ranah kognitif, afektif, psikomotor dan interaktif sesuai dengan tujuan belajar. Perubahan itu dapat pula diperoleh seseorang melalui lembaga pendidikan. Sikap merupakan reaksi atau respon seseorang yang masih tertutup terhadap stimulus atau objek (Notoatmodjo, 2012).

Hasil penelitian ini juga didukung oleh hasil penelitian Lestari dkk (2016) ada pengaruh yang besar terhadap pengetahuan dan skill santri putri di Pondok Pesantren Dawar Kabupaten Boyolali sebelum dan sesudah diberikan edukasi, sejalan pula dengan hasil penelitian Ernawati (2016). ada pengaruh edukasi kelompok terhadap tindakan ibu dalam pemberian ASI ekslusif. Penelitian Handayani dan Aprilina (2017) menyatakan bahwa setelah pelatihan tentang ASI eksklusif pengetahuan dan pemahaman peserta tentang ASI eksklusif bertambah dan mendapatkan informasi baru.

Pentingnya pemberdayaan keluarga dan kader kesehatan dalam pelaksanaan pemberian ASI ekslusif sesuai dengan penelitian Sartono dan Utaminingrum (2012) bahwa dukungan keluarga terutama suami dapat menentukan keberhasilan ibu 
menyusui, dukungan suami akan memberikan rasa nyaman pada ibu yang dapat mempengaruhi produksi ASI, meningkatkan semangat dan memberikan rasa nyaman saat ibu menyusui. Menurut Handayani dan Aprilina (2017) kesuksesan pemberian ASI eksklusif juga memerlukan banyak dukungan dan partisipasi dari berbagai fihak termasuk dari kader kesehatan karena kader kesehatan orang yang sering bersosialisasi dengan masyarakat termasuk ibu hamil dan menyusui.

\section{Simpulan}

Setelah dilakukan kegiatan pengabdian pada masyarakat melalui pelatihan keluarga dan kader kesehatan tentang manfaat ASI eksklusif terdapat pengaruh yang signifikan tentang pengetahuan dan skill peserta pelatihan sebelum dan sesudah pelatihan.

Keluarga dan kader kesehatan yang merupkan orang terdekat yang dapat mempengaruhi ibu untuk memberikan ASI eksklusif pada bayinya. Setelah kegiatan pelatihan ini diharapkan keluarga dan kader kesehatan dapat berperan aktif untuk menyampaikan informasi kepada ibu hamil tentang manfaat ASI Aksklusif.

\section{Daftar Pustaka}

Badan Penelitian dan Pengembangan Kesehatan Kementerian Kesehatan RI. (2010). Riset Kesehatan Dasar (Kementeria). Jakarta.

Baskoro, A. (2008). ASI Panduan Praktis Ibu Menyusui. Yogyakarta: BANYU MEDIA. Dr, Arisman, M. (2010). Buku Ajar Ilmu Gizi (2nd ed.). Jakarta: EGC.

Ernawati, B., \& Tahlil, T. (2016). Peningkatan Pengetahuan, Sikap Dan Tindakan Ibu Dalam Memberikan Asi Eksklusif Melalui Edukasi Kelompok. Jurnal Ilmu Keperawatan, 4(2).

Fikawati, S., \& Syafiq, A. (2010). Kajian implementasi dan kebijakan air susu ibu eksklusif dan inisiasi menyusu dini di Indonesia. Makara Kesehatan, 14(1), 17-24.

Handayani, D. Y., \& Aprilina, H. A. (2017). Pemberdayaan Kader Posyandu Dalam Program ASI Ekslusif Di Desa Pamijen, Sokaraja, Banyumas. MEDISAINS, 13(1).

Hilala, A. (2014). Faktor-faktor Yang Berhubungan Dengan Pemberian ASI Esklusif Di Wilayah Kerja Puskesmas Tuladenggi Kecamatan Telaga Biru Kabupaten Gorontalo Tahun 2013. Universitas Negeri Gorontalo.

Kementrian Kesehatan Republik Indonesia. (2011). Profil Kesehatan Indonesia 2010. Jakarta: Kementerian Kesehatan Republik Indonesia.

Lestari, D. P., Prabamurti, P. N., \& Husodo, B. T. (2016). Pengaruh Penyuluhan 
Kesehatan terhadap Pengetahuan, Sikap dan Praktik Periksa Payudara Sendiri (Sadari) Santri Putri Pondok Pesantren Dawar Kabupaten Boyolali. Jurnal Kesehatan Masyarakat Universitas Diponegoro, 4(5), 291-298.

Manuaba. (2009). Ilmu Kebidanan, Penyakit Kandungan dan KB. Jakarta: EGC.

Notoatmodjo, P. D. S. (2012). Pendidikan Dan Perilaku Kesehatan. Jakarta: Rineka Cipta.

Notoatmojo, S. (2012). Promosi Kesehatan dan Perilaku Kesehatan. Jakarta: Rineka Cipta.

Roesali, U. (2008). Inisiasi Menyusui Dini Plus ASI Eksklusif. Jakarta: Pustaka Bunda.

Sartono, A., \& Utaminingrum, H. (2012). Hubungan Pengetahuan Ibu, Pendidikan Ibu dan Dukungan Suami dengan Praktek Pemberian Asi Eksklusif di Kelurahan Muktiharjo Kidul Kecamatan Telogosari Kota Semarang. Jurnal Gizi, 1(1).

Soetiningsih. (2012). ASI Petunjuk Untuk Tenaga Kesehatan. Jakarta: EGC. 